\title{
Birth weight symposium
}

\section{Nick Mann}

\section{Introduction to the Birth weight symposium}

W hat factors determine birth weight and do they have any biological significance for the future health and welfare of the individual? These are important questions for all paediatricians and four groups of experts have been approached to independently give their thoughts on key areas. The aim was for concise pithy comments and opinions, so the length of the articles was rigourously controlled. Firstly, are there genetic factors that genetic and environmental factors of parental, placental, and fetal origin.

\section{Parental genes}

Parental genetic influences are likely to be polygenic, but the exact genes involved and how they act is not fully understood. Glucokinase provides an elegant example of the effect of a parental genetic variant and also shows the interaction between parental and fetal genotypes. Mutations in this gene have been found to cause maturity onset diabetes of the young type $2 .{ }^{8}$ Hattersley and colleagues investigated the influence of glucokinase gene defects on birth size in 58 offspring where one parent was known to be affected. ${ }^{9}$ If a mother had a glucokinase mutation, the birth weight was increased by a mean $601 \mathrm{~g}$ as a result of maternal hyperglycaemia in pregnancy. If a fetus had inherited a glucokinase mutation, the birth weight was decreased by $533 \mathrm{~g}$, equivalent to a fall from the 50th to the 25 th birth weight centile. An affected mother resulted in a rise from the 50th to the 85th centile in an unaffected child, or the 25 th to the 50th centile in an affected child.

\section{Placental genes}

The placenta is critically involved in transporting nutrition and acting as a barrier to infection and maternal corticosteroids. In most cases, it is genetically identical with the fetus, but in $1-2 \%$ of conceptuses confined placental mosaicism is observed, in which a cytogenetic abnormality is detected in the placenta and not the fetus. ${ }^{10}{ }^{11}$ Up to $20 \%$ of idiopathic SGA term deliveries have confined placental mosaicism. ${ }^{11}{ }^{12}$ How mosaicism affects fetal growth

\section{WHICH GENETIC FACTORS INFLUENCE BIRTH WEIGHT?}

Birth size is the result of fetal growth. The fetal experience is unique and influenced by parental, placental, and fetal factors. Furthermore, it is likely that there are complex interactions between
Abbreviations: IGF, insulin-like growth factor; SGA, small for gestational age dehydrogenase.
Familial trends in birth weight have also been observed. There is significant correlation between parental birth weights 
is not known, but presumably it is related to an alteration of placental function.

\section{Fetal genes}

Insight into the genes that may be involved in human fetal growth has been provided by studies on human and animal fetal physiology. In particular, mouse gene knockout studies have clearly shown that insulin-like growth factor (IGF)-I, IGF-II, IGF receptor type 1 , insulin, insulin receptor, and insulin receptor substrate 1 are all critical for normal fetal growth. ${ }^{13-16}$

In humans, the first single gene defect in a short SGA subject was found in the IGF-I gene. ${ }^{17} \mathrm{~A}$ homozygous deletion of exons 4 and 5 of the IGF-I gene resulted in undetectable levels of serum IGF-I, extreme intrauterine growth retardation, severe postnatal growth failure, deafness, and moderate learning difficulties. This case shows that, in man, an IGF-I gene defect can be compatible with life whereas there is high mortality in the knockout mice as a result of respiratory muscle weakness. ${ }^{13} 14$

Studies of the insulin gene in the Avon Longitudinal Study of Pregnancy and Childhood (ALSPAC) subcohort of 758 term singletons found a significant association of the insulin variable number tandem repeat class III genotype and longer length, weight, and head circumference at birth in children who did not change weight centile from birth to 2 years. ${ }^{18}$ Children homozygous for the class III allele showed a $200 \mathrm{~g}$ increase in birth weight. There was no association of genotype with birth size in the group as a whole, which the authors argued was due to the effect of environmental factors.

Detailed genetic studies have been performed in children with SilverRussell syndrome, but no consistent cytogenetic abnormalities have been found. However, it has been shown that $10 \%$ of these children have inherited two copies of the maternal chromosome 7 and no paternal copy (uniparental disomy; mUPD7). ${ }^{19-21}$ This suggests that there may be a recessive gene defect if there is isodisomy-that is, two copies of the same chromosome are inherited-or an imprinted paternally expressed gene if there is heterodisomy-that is, both maternal chromosomes 7 are inherited-in this region. There are several good candidate genes in the two regions of interest ( $7 \mathrm{pl} 2-13$ and $7 \mathrm{q} 32$ ) that are homologous to imprinted regions in the mouse genome. Molecular studies have not yet found the causative $\operatorname{defect}(\mathrm{s})$.

\section{CONCLUSIONS}

Epidemiological studies have shown that genetic factors account for $38-80 \%$ birth weight variance. There is growing evidence supporting the roles of certain candidate genes in influencing size at birth. Many more genetic influences remain to be discovered. Furthermore, an understanding of how these factors interact will be necessary before this knowledge can be fully exploited.

Arch Dis Child Fetal Neonatal Ed 2002;86: F2-F3

\section{Authors' affiliations}

L B Johnston, A J L Clark, M O Savage,

Department of Endocrinology, St Bartholomew's and the Royal London Schools of Medicine and Dentistry, Queen Mary, University of London, London, UK

Correspondence to: Professor Savage, Paediatric Endocrine Section, St Bartholomew's Hospital, West Smithfield, London EC1A 7BE, UK; m.o.savage@mds.qmw.ac.uk

\section{REFERENCES}

Magnus P, Berg K, Bjerkedal T, et al Parental determinants of birth weight. Clin Genet 1984;26:397-405

2 Magnus P. Causes of variation in birth weight: a study of offspring of twins. Clin Genet 1984;25:15-24.

3 Penrose LS. Some recent trends in human genetics. Caryologia 1954;6(suppl):521-30

4 Langhoff-Roos J, Lindmark G, Gustavson $\mathrm{KH}$, et al. Relative effect of parental birth weight on infant birth weight at term. Clin Genet 1987;32:240-8.

5 Magnus P, Bakketeig LS, Hoffman H. Birth weight of relatives by maternal tendency to repeat small-for-gestational-age (SGA) births in successive pregnancies. Acta Obstet Gynecol Scand Suppl 1997; 165:35-8.

6 Wang X, Zuckerman B, Coffman GA, et al Familial aggregation of low birth weight among whites and blacks in the United States. N Engl J Med 1995;333:1744-9.

7 Magnus P. Further evidence for a significant effect of fetal genes on variation in birth weight. Clin Genet 1984;26:289-96.

8 Velho G, Froguel P. Genetic, metabolic and clinical characteristics of maturity onset diabetes of the young. Eur J Endocrinol 1998; 138:233-9.

9 Hattersley AT, Beards F, Ballantyne E, et al. Mutations in the glucokinase gene of the fetus result in reduced birth weight. Nat Genet 1998; 19:268-70.

10 Lestou VS, Kalousek DK. Confined placental mosaicism and intrauterine fetal growth. Arch Dis Child Fetal Neonatal Ed 1998;79:F223-6.

11 Kalousek DK, Dill FJ. Chromosomal mosaicism confined to the placenta in human conceptions. Science 1983;221:665-7.

12 Wilkins-Haug L, Roberts DJ, Morton CC. Confined placental mosaicism and intrauterine growth retardation: a case-control analysis of placentas at delivery. Am J Obstet Gynecol 1995; 172:44-50.

13 Liu JP, Baker J, Perkins AS, et al. Mice carrying null mutations of the genes encoding insulin-like growth factor I (lgf-1) and type 1 IGF receptor (lgflr). Cell 1993;75:59-72.

14 Baker J, Liu JP, Robertson EJ, et al. Role of insulin-like growth factors in embryonic and postnatal growth. Role of insulin-like growth factors in embryonic and postnatal growth. Cell 1993;75:73-82

15 Tamemoto $\mathbf{H}$, Kadowaki T, Tobe K, et al. Insulin resistance and growth retardation in mice lacking insulin receptor substrate-1. Nature 1994;372:182-6.

16 Accili D, Nakae J, Kim JJ, et al. Targeted gene mutations define the roles of insulin and IGF-I receptors in mouse embryonic development. J Pediatr Endocrinol Metab 1999; 12:475-85.

17 Woods KA, Camacho-Hubner C, Savage $M O$, et al. Intrauterine growth retardation and postnatal growth failure associated with deletion of the insulin-like growth factor I gene. N Engl J Med 1996;335:1363-7.

18 Dunger DB, Ong KK, Huxtable SJ, et al. Association of the INS VNTR with size at birth. ALSPAC Study Team. Avon Longitudinal Study of Pregnancy and Childhood. Nat Genet 1998;19:98-100.

19 Eggermann T, Wollmann HA, Kuner R, et al. Molecular studies in 37 Silver-Russell syndrome patients: frequency and etiology of uniparental disomy. Hum Genet 1997; 100:415-19.

20 Preece MA, Price SM, Davies V, et al. Maternal uniparental disomy 7 in Silver-Russell syndrome. J Med Genet 1997;34:6-9.

21 Kotzot D, Schmitt S, Bernasconi F, et al. Uniparental disomy 7 in Silver-Russell syndrome and primordial growth retardation. Hum Mol Genet 1995;4:583-7. 


\section{Maternal nutrition as a determinant of birth weight}

\section{T Stephenson, M E Symonds}

Maternal nutrition, encompassing maternal dietary intake, circulating concentrations, uteroplacental blood flow, and nutrient transfer across the placenta, influences birth weight

\section{THE CONTRIBUTION OF MATERNAL NUTRITION TO BIRTH WEIGHT}

Birth weight is correlated between hal siblings of the same mother but not of the same father ${ }^{1}$ because of the greater and environment. ${ }^{2}$ As summarised in table 1 , the latter includes maternal nutrition.

\section{MATERNAL NUTRITION AND CLINICALLY SIGNIFICANT INTRAUTERINE GROWTH RESTRICTION}

In the narrow sense, "maternal nutrition" describes the pregnant woman's diet. The effects of severe macronutrient deficiency depend on the stage of gestation. During the Dutch famine of 1944 1945 , a $50 \%$ reduction in energy intake during the first trimester was associated with increased placental weight but no change in birth weight. ${ }^{4}$ Maternal undernutrition in late gestation was associated with reduced placental and fetal weights.

\section{"The effects of severe macronutrient deficiency depend on the stage of gestation."}

Embryo transfer and litter reduction experiments similarly show that maternal environment predominantly influences later fetal growth. ${ }^{5}$ Although macronutrient deficits in later pregnancy would be expected to exert greatest impact on birth weight (the human fetus weighs only $20 \%$ of term weight at 24 weeks $\left.{ }^{3}\right)$, catch up growth often occurs. ${ }^{67}$ In contrast, the earlier in postnatal life that undernutrition occurs, the more likely it is to have permanent-that is, programming_effects. ${ }^{8}$ In normal pregnancies of malnourished women, dietary

Abbreviations: $11 \beta-H S D, 11 \beta$-hydroxysteroid dehydrogenase. contribution of the maternal genotype supplementation during late pregnancy increases birth weight.'

\section{MATERNAL NUTRITION AND VARIATION WITHIN THE NORM: THE BARKER HYPOTHESIS}

In developed countries, dietary macronutrient or micronutrient deficiency are rarely thought to be responsible for clinically significant impaired fetal growth. ${ }^{10}$ Lower birth weight is associated with lower social class, but although it is often assumed that this is nutritional, there are many confounders such as smoking and genetic factors. Recent human pregnancy studies do not confirm the dietary hypothesis, ${ }^{11}{ }^{12}$ but these studies have been criticised. ${ }^{13}$ Contemporary studies in Australia, however, indicate that nearly $30 \%$ of women who deliver babies with a low birth weight $(<2500 \mathrm{~g})$ suffer from eating disorders. ${ }^{14}$ Experimentally increasing maternal nutrition in sheep enhances birth weight. ${ }^{13}$

Epidemiological studies have shown that size at birth and/or placental weight predict adult disease. ${ }^{15}{ }^{16}$ The hypothesis that variations in maternal diet within the normal range can lead to concomitant variations in birth weight and hence to later disease remains the subject of intense debate. These studies are criticised because of possible confounding factors. However, later blood pressure is

Table 1 Genetic and environmental contributions (\%) to birth weight variation (adapted from James \& Stephenson ${ }^{3}$ )

Genetic Maternal genotype 20 Fetal genotype

Fetal sex

Total genetic contribution 38

Environmental

General maternal environment Immediate maternal environment Maternal age and parity Unknown environmental influences

Total environmental contribution independent of maternal blood pressure and smoking,${ }^{17}$ social class at birth, adult social class, later cigarette smoking, and obesity. ${ }^{15}$ In the Hertfordshire cohort, ${ }^{18}$ birth weight is unrelated to social class either at birth or currently. ${ }^{15}$ Moreover, birth weight was not associated with lung cancer or deaths from noncardiovascular causes, which may also be expected to be influenced by social class and lifestyle.

\section{FETAL SUBSTRATE SUPPLY}

So far, this review has focused on the mother's dietary intake. In the wider sense, maternal "nutrition" encompasses the complete supply line of maternal intake, circulating concentrations, uteroplacental blood flow, and nutrient transfer across the placenta. ${ }^{3}$ Experimental reduction of the number of placentomes in sheep results in a smaller fetus, ${ }^{19}$ as does reduction in uterine artery blood flow. $^{20}$ Maternal smoking $^{21}$ and pre-eclampsia are associated with lower birth weight. ${ }^{22}$ Nutritional or vascular factors probably account for the association between lower birth weight and placental anomalies, twin-twin transfusion syndrome, and maternal diseases (respiratory, cardiac, renal, and collagen). ${ }^{23}$ Nutrition is a dominant influence on insulin-like growth factor-I concentrations prenatally, ${ }^{24}$ and the correlation between birth weight and insulin-like growth factor- $\mathrm{I}^{25}$ is further evidence that nutrition, in this broader sense, is a determinant of birth weight.

However, most fetuses with clinical intrauterine growth restriction have a reduced placental to birth weight ratio, suggesting that the fetus adapts to improve placental transfer when the placenta is pathologically small. In contrast, in Barker's studies of predominantly healthy (and surviving) infants from 50 years ago, it was men with a high placental to birth weight ratio who had highest death rates from cardiovascular disease, ${ }^{15}$ suggesting different mechanisms. The association between maternal anaemia and increased placental weight ${ }^{26}{ }^{27}$ could be linked by nutrition or oxygen delivery.

In the Dutch famine, dietary restriction during early gestation increased the placental to birth weight ratio and resulted in a much greater risk of adult coronary heart disease and obesity. ${ }^{28}$ In a sheep model, maternal nutrient restriction between early to mid gestation resulted in increased placental weight but not fetal weight at term. ${ }^{29}$

HOW COULD MATERNAL NUTRITION PROGRAMME RISK IN LATER LIFE DESPITE A BIRTH WEIGHT IN THE NORMAL RANGE?

Small for gestational age does not necessarily equate with intrauterine growth 
restriction. Even if birth weight remains within the normal range, this may conceal a birth weight significantly below genetic potential because of suboptimal maternal or fetal nutrition. ${ }^{30}$ Nutritional deprivation redistributes maternal cardiac output away from the uterine vasculature, ${ }^{31}$ and a chronic fetal "stress response" to this could permanently reprogramme steroid sensitivity. Fetal overexposure to maternal glucocorticoids may programme hypertension ${ }^{32}$. $^{33}$ In sheep, dexamethasone treatment during early pregnancy results in persistent hypertension in the offspring. ${ }^{34}$

Sensitivity to glucocorticoids is regulated by expression of the glucocorticoid receptor and $11 \beta$-hydroxysteroid dehydrogenase (11 $\beta$-HSD). $11 \beta$-HSDl catalyses the conversion of cortisone to the more potent cortisol, ${ }^{35}{ }^{36}$ and 11 $\beta$-HSD2 does the opposite, "protecting" the fetus from adverse glucocorticoid exposure. $^{32}{ }^{37}$ The renin-angiotensin system is also regulated by glucocorticoids ${ }^{38}$ and is critical to the control of blood pressure during fetal and postnatal life. ${ }^{39}{ }^{40}$ Increased tissue exposure to cortisol could explain how early reduction in maternal nutrition affects fetal cardiovascular development while birth weight remains within the normal range.

In the sheep model with maternal nutrient restriction in early gestation and increased placental to fetal weight ratio at term, ${ }^{29}$ both glucocorticoid and type 1 angiotensin II receptor mRNA expression are increased in the offsprings' adrenal and kidney. ${ }^{41}$ Conversely, placental 11 $\beta$-HSD2 mRNA expression is decreased, which could increase cortisol transfer across the placenta in the absence of any apparent change in maternal cortisol. ${ }^{42}{ }^{43}$

\section{CONCLUSIONS}

In developing countries, maternal dietary intake can affect birth weight, and intervention helps. In developed countries, epidemiological studies and experiments using animals indicate that modest reductions in maternal food intake could affect survival at birth and longevity, in the absence of pathological changes in birth weight. ${ }^{44}{ }^{45}$ It appears to be earlier maternal nutrient restriction that increases placental size ${ }^{29}$ and alters the expression of genes regulating the glucocorticoid and renin-angiotensin systems. ${ }^{41}$

Arch Dis Child Fetal Neonatal Ed 2002;86: F4-F6

\section{Authors' affiliations}

T Stephenson, M E Symonds, Academic Division of Child Health, School of Human Development, University Hospital, Nottingham NG7 2UH, ÚK

Correspondence to: Professor Stephenson; terence.stephenson@nottingham.ac.uk

\section{REFERENCES}

1 Gluckman P, Harding JE. Nutritional and hormonal regulation of fetal growth: evolving concepts. Acta Paediatr Suppl

1994:399:60-3.

2 Walton A, Hammond J. The maternal effects on growth and conformation in Shire horse-Sheltand pony crosses. Proc $R$ Soc Lond B Biol Sci 1954:125:31 1-35.

3 James DK, Stephenson TJ. Fetal nutrition and growth. In: Chamberlain G, Broughton Pipkin $\mathrm{F}$, eds. Clinical physiology in obstetrics. Oxford: Blackwell Science, 1998:467-97.

4 Lumey LH. Compensatory placental growth after restricted nutrition in early pregnancy. Placenta 1998;19:105-12.

5 Snow MHL. Effect of genome on size at birth. In: Sharp F, Milner R, Fraser R, eds. Fetal growth. London: Royal College of Obstetricians and Gynaecologists, 1989:3-12

6 Coutant R, Carel JC, Letrat $M$, et al. Short stature associated with intrauterine growth retardation: final height of untreated and growth hormone treated children. J Clin Endocrinol Metab 1998:83:1070-4.

7 Fewtrell MS, Morley R, Abbott RA, et al. Catch-up growth in small for gestational age term infants: a randomised trial. Am J Clin Nutr 2001;74:516-23.

8 Widdowson EM, McCance RA. The effect of finite periods of undernutrition at different ages on the composition and subsequen development of the rat. Proc $R$ Soc Lond 1963;158:329-42.

9 Prentice AM. Can maternal dietary supplements help in preventing infant malnutrition? Acta Paediatr Suppl 1991;374:67-77.

10 Robinson JS, Moore V, Owens JA, et al. Origins of fetal growth restriction. Eur J Obstet Gynecol Reprod Biol 2000;92:13-19.

11 Godfrey K, Robinson S. Maternal nutrition, placental growth and fetal programming. Proc Nutr Soc 1997;57:105-111.

12 Mathews F, Yudkin P, Neil A. Influence of maternal nutrition on outcome of pregnancy: prospective cohort study. $B M$ 1999;319:339-43.

13 Symonds ME, Budge $H$, Stephenson $T$. Limitations of models used to examine the influence of nutrition during pregnancy and adult disease. Arch Dis Child 2000;83:215-19.

14 Conti J, Abraham S, Taylor A. Eating behaviour and pregnancy outcome. $J$ Psychosom Res 1998;44:465-77

15 Barker DJP. Mothers, babies and disease in later life. 2nd ed. Edinburgh: Churchill Livingstone, 1998.

16 Huxley RH, Sheill AW, Law CM. The role of size at birth and postnatal catch-up growth in determining systolic blood pressure: a systematic review of the literature. J Hypertens 2000;18:815-31

17 Law CM, Barker DJP, Bull AR, et al. Maternal and fetal influences on blood pressure. Arch Dis Child 2000;66:1291-5.

18 Barker DJP, Winter PD, Osmond C, et al. Weight in infancy and death from ischaemic heart disease. Lancet 1989;ii:577-80.

19 Owens JA, Owens PC, Robinson JS. Experimental restriction of growth. In: Hanson MA, Spencer JAD, Rodeck CH, eds. The fetus and neonate. Volume 3: growth. Cambridge: Cambridge University Press, 1995: 139-75.

20 Charlton $\mathbf{V}$, Johengen $M$. Fetal intravenous nutritional supplementation ameliorated the development of embolization induced growth retardation in sheep. Pediatr Res 1987;22:55-61.

21 Anderson GD, Blinder IN, McClemont S, et al. Determinants of size at birth in a Canadian population. Am J Obstet Gynecol 1984; 150:236-44.

22 Broughton Pipkin F, Roberts JM Hypertension in pregnancy. J Hum Hypertens 2000;14:705-24.

23 Robinson JS, Owens JA. Control of fetal growth. In: Hillier SG, Kitchen HC, Neilson JP, eds. Scientific essentials of human reproduction. London: WB Saunders, 1995:329-41.
24 Bauer MK, Breier BH, Harding J, et al. The fetal somatotrophic axis during long term maternal undernutrition in sheep: evidence of nutritional regulation in utero. Endocrinology 1995; 136:1250-7

25 Spencer JAD, Chang TC, Jones J, et al. Third trimester fetal growth and umbilical venous blood concentrations of IGF-1, IGFBP-1, and growth hormone at term. Arch Dis Child 1995;73:F87-90.

26 Beischer NA, Sivasamboo R, Vohra S, et al. Placental hypertrophy in severe pregnancy anaemia. J Obstet Gynaecol Br Commonw 1970;77:398-409.

27 Godfrey KM, Redman CWG, Barker DJP, et al. The effect of maternal anaemia and iron deficiency on the ratio of fetal weight to placental weight. J Obstet Gynaecol Br Commonw 1991;98:886-91.

28 Roseboom TJ, van der Meulen JHP, Osmond $C$, et al. Coronary heart disease in adults after perinatal exposure to famine. Heart 2000;84:595-8

29 Heasman L, Clarke L, Firth K, et al. Influence of restricted maternal nutrition in early to mid gestation on placental and fetal development at term. Pediatr Res 1998;44:546-51.

30 Altman DG, Hytten FE. Intrauterine growth retardation: let's be clear about it. Br J Obstet Gynaecol 1989;96:1 127-32.

31 Morris FH, Rosenfield CR, Crandell SS, et al. Effects of fasting on uterine blood flow and substrate uptake in the sheep. J Nutr 1980;1 10:2433-43

32 Langley-Evans SC, Phillips GJ, Benediktsson $R$, et al. Protein intake in pregnancy, placental glucocorticoid metabolism and the programming of hypertension. Placenta 1996;17:169-72.

33 Lindsay RS, Lindsay RM, Edwards CRW, ef al. Inhibition of $11 \beta$-hydroxysteroid dehydrogenase in pregnant rats and the programming of blood pressure in offspring. Hypertension 1996;27:1200-4.

34 Dodic M, May CN, Wintour EM, et al. An early prenatal exposure to excess glucocorticoid leads to hypertensive offspring in sheep. Clin Sci 1998;94. 149-55.

35 Bamberger CM, Schulte HM, Chrousos GP. Molecular determinants of glucocorticoid receptor function and tissue sensitivity to glucocorticoids. Endocr Rev 1996;17:245-61.

36 Stewart PM, Krozowski ZS $11 \beta$-Hydroxysteroid dehydrogenase. Vitam Horm 1999;57:249-324

37 Tangalakis K, Lumbers ER, Moritz KM, et al. Effects of cortisol on blood pressure and vascular reactivity in the ovine fetus. Exp Physiol 1992;77:709-19.

38 Sato A, Suzuki H, Murakami M, et al. Glucocorticoid increases angiotensin II type receptor and its gene expression. Hypertension 1994;23:25-30.

39 Lumbers ER. Functions of the renin-angiotensin system during development. Clin Exp Pharmacol Physiol 1995;22:499-505

40 Stephenson T, Broughton Pipkin F Elias-Jones AC. A study of factors influencing plasma renin and renin substrate concentrations in the premature human newborn. Arch Dis Child 1991;66 $1150-4$

41 Whorwood CB, Firth KM, Budge $\mathrm{H}$, et al Maternal undernutrition during early- to mid-gestation programmes tissue-specific alterations in the expression of the glucocorticoid receptor, $11 \beta$-hydroxysteroid dehydrogenase isoforms and type 1 angiotensin II receptor in neonatal sheep. Endocrinology 2001; 142 2854-64.

42 Dandrea J, Stephenson T, Symonds ME. Maternal undernutrition in early to mid gestation does not affect plasma cortisol in 
sheep individually housed within sight and sound of conspecifics. J Endocrinol 1999; 163(suppl):P70

43 Brameld JM, Mostyn A, Dandrea J, et al. Maternal nutrition alters the expression of insulin-like growth factors in fetal sheep liver and skeletal muscle. J Endocrinol 2000; 167:429-37.

44 Ravelli ACJ, van der Meulin JHP, Michels RPJ, et al. Glucose tolerance in adults after in utero exposure to the Dutch famine. Lancet 1998;351:173-7.
45 Heasman L, Clarke L, Stephenson T, et al. Effect of maternal nutrient restriction in early to mid gestation and thyrotrophin-releasing hormone on lamb survival following Caesarean section delivery near to term. Can J Physiol Pharmacol 2000;78:571-7.

\section{Social influences on birth weight}

\section{N Spencer, S Logan}

Risk factors for low birth weight are strongly influenced by the social environment

B irth weight, like growth, is determined by the complex interplay of genetic and environmental factors. The proportional contribution of these influences is unclear. However, birth weight varies within genetically similar populations, ${ }^{1-3}$ suggesting that environmental factors play a significant role. Secular changes in birth weight ${ }^{4}$ also suggest an environmental influence. Birth weight also shows a reverse social gradient such that increasing disadvantage is associated with decreasing birth weight. ${ }^{1-3}$

\section{ENVIRONMENTAL FACTORS AFFECTING BIRTH WEIGHT}

Environmental factors with a known association with birth weight are nutrition, smoking, maternal ill health, and genital infection. The association of other factors such as stress ${ }^{5}$ and exposure to some types of work during pregnancy $^{6}$ remains unproven. Other risk factors for low birth weight such as maternal age, although not themselves environmental factors, are strongly influenced by the social environment.

Severe energy restriction during pregnancy, such as occurs in some developing countries $^{7}$ and was noted in the 1945 Dutch Hunger Winter ${ }^{8}$, reduces birth weight but, randomised controlled trials of nutritional interventions in the index pregnancy have failed to show convincing benefit. ${ }^{9}$ Nutrition may exert its effect over a longer period through an effect on maternal growth in childhood ${ }^{10}$ and possibly through an intergenerational effect. ${ }^{11}$ Adult height has a known association with relative nutritional impairment in childhood, ${ }^{12}$ and maternal height is an important determinant of birth weight. ${ }^{13}$

The association of smoking with a reduction in birth weight is well established. ${ }^{13}$ Maternal ill health has been associated with reduced birth weight, ${ }^{14}$ and genital infection exerts its

influence through increasing the risk of preterm delivery. ${ }^{15}$

Evidence for an independent effect of stress is slight, but one study does show stress exerting an effect through increased smoking. ${ }^{16}$

\section{SOCIAL GRADIENT IN BIRTH WEIGHT}

Given the importance of birth weight for infant, childhood, and adult health, ${ }^{17}$ a 150-200 g social gradient in mean birth weight and $30 \%$ of births less than 2500 $\mathrm{g}$ attributable to social inequalities ${ }^{1}$ is a key public health issue. Reductions in inequalities in infant mortality and many childhood and adult health inequalities, key government health targets, ${ }^{18}$ are unlikely to be achieved without a narrowing of the social gradient in birth weight. Interventions to increase birth weight in disadvantaged groups have been largely unsuccessful, ${ }^{19}$ and, although mean birth weight has increased, ${ }^{20}$ the rate of change is slow and the gradient remains unchanged.

\section{"Reductions in inequalities in infant mortality and many childhood and adult health inequalities, key government health targets, are unlikely to be achieved without a narrowing of the social gradient in birth weight."}

The failure of interventions to influence the social gradient is likely to result from a focus on modifying individual risk factors such as smoking, diet, and infection in the already established pregnancy with the intervention starting around 16 weeks at the earliest. The social gradient in birth weight probably arises as a result of the accumulation and addition of risk and protective factors over time ${ }^{21}$ and across generations ${ }^{11}$ rather than resulting from risk exposures within the index pregnancy. Poor socioeconomic circumstances in early life may lead to biological vulnerability in later life, ${ }^{22}$ and adult health behaviours seem to have socioeconomic roots early in life. ${ }^{23}$ A woman whose parents were disadvantaged is more likely to have been low birth weight herself, to have experienced more childhood ill health, to have had a less nutritious diet with adverse effect on her growth, to have started smoking in adolescence and be less likely to quit in early pregnancy, and to come to pregnancy at an earlier age.

Although innovative approaches to smoking cessation and stress reduction may have some effect in the short term, reduction of the social gradient is likely to be a long term goal requiring attention to the nutritional and health status of young children. Of equal importance will be improving the overall social environment in which children grow up so that protective factors, such as maternal education, become more evenly distributed across social groups and risk factors are reduced in disadvantaged groups.

Arch Dis Child Fetal Neonatal Ed 2002;86: F6-F7

Authors' affiliations

N Spencer, Department of Child Health, School of Postgraduate Medical Education and School of Health and Social Studies, University of Warwick, Coventry CV4 7AL, UK $S$ Logan, Department of Epidemiology and Biostatistics, Institute of Child Health, London, UK

Correspondence to: Professor Spencer; n.j.spencer@warwick.ac.uk

\section{REFERENCES}

1 Spencer NJ, Bambang S, Logan S, et al. Socio-economic status and birth weight: comparison of an area-based measure with the Registrar General's social class. J Epidemiol Community Health 1999:53:495-8.

2 Elmen $H$, Hoglund D, Karlberg P, et al. Birth weight for gestational age as a health indicator: birth weight and mortality measures at a local level. Eur J Public Health 1996:6:137-41.

3 Mackenbach JP. Socio-economic health differences in the Netherlands: a review of recent empirical findings. Soc Sci Med 1992;34:213-26.

4 Power C. National trends in birth weight: implications for future adult disease. BM 1994;308: 1270-1

5 Hoffman S, Hatch MC. Stress, social support and pregnancy outcome: a reassessment based on recent research. Paediatr Perinat Epidemiol 1996;10:380-405. 
6 Homer CJ, James SA, Siegel E. Work-related psychosocial stress and risk of preterm, low birth weight delivery. Am J Public Health 1989:80:173-7.

7 Achadi EL, Hansell MJ, Sloan NL, et al. Women's nutritional status, iron consumption and weight gain during pregnancy in relation to neonatal weight and length in West Java, Indonesia. Int J Gynaecol Obstet 1995:48(suppl):S103-19.

8 Hart N. Famine, maternal nutrition and infant mortality: a re-examination of the Dutch Hunger Winter. Popul Stud (Camb) 1993;47:27-46.

9 Kramer MS. Balanced protein/energy supplementation in pregnancy (Cochrane Review). In: Cochrane Library, Issue 4, 1998

10 Baird D. Environment and reproduction. Br J Obstet Gynaecol 1980;87:1057-67.

11 Emanuel I, Filakti $\mathrm{H}$, Alberman $\mathrm{E}$, et al. Intergenerational studies of human birth weight from the 1958 birth cohort. 1. Evidence for a multigenerational effect. $\mathrm{Br} J$ Obstet Gynaecol 1992;99:67-74.
12 Berney L, Blane D, Davey Smith G, et al. Lifecourse influences on health in early old age. In: Graham H, ed. Understanding health inequalities. Buckingham and Philadelphia: Open University Press, 2000.

13 Kramer MS. Determinants of low birth weight: methodological assessment and meta-analysis. Bull WHO 1987;65 666-737

14 Baird D. The epidemiology of low birth weight: changes in incidence in Aberdeen, 1948-72. J Biosoc Sci 1974;6: 623-41.

15 Divers MJ, Lilford RJ. Infection and preterm labour: a meta-analysis. Contemporary Reviews of Obstetrics and Gynaecology 1993;5:71-84

16 Sheehan TJ. Stress and low birth weight: a structural modeling approach using real life stressors. Soc Sci Med 1998:47:1503-12.

17 Barker DJP, ed. Fetal and infant origins of adult disease. London: BM Publications Group, 1992
18 Department of Health. Health Inequalities: Health Secretary announces new plans to improve health in poorest areas: 28th February, 2001. http://www.doh.gov.uk/ healthinequalities/press.htm.

19 Paneth NS. The problem of low birth weight. The Future of Children 1995;5:20-32.

20 Alberman E. Are our babies becoming bigger? J R Soc Med 1991;84:257-60.

21 Kuh D, Power C, Blane D, et al. Social pathways between childhood and adult health. In: Kuh D and Ben-Shlomo Y, eds. A life course approach to chronic disease epidemiology. Oxford: Oxford Medical Publications, 1997.

22 Wadsworth MEJ. Health inequalities in the life course perspective. Soc Sci Med 1997;44:859-69.

23 Lynch JW, Kaplan GA, Salonen JT. Why do poor people behave poorly? Variation in adult health behaviours and psychosocial characteristics by stages of the socioeconomic lifecourse. Soc Sci Med 1997;44: 809-19.

cardiovascular disease and the evidence against the control of fetal growth being primarily genetic argue against pure genetic causes.

\section{PROGRAMMING HYPOTHESIS}

The programming hypothesis is a plausible explanation of the associations of birth weight with adult health. Programming occurs when an event in a critical early period of an organism's life permanently changes structure or function, and is well described in experimental biology. ${ }^{16}$ Under a programming hypothesis, the fetus, which is highly plastic, adapts to adverse influences, such as undernutrition or hypoxia, in order to ensure its immediate survival. These adaptations are accompanied by reduced fetal growth. However, the adaptations may also lead to detrimental effects in postnatal health. For example, shunting of blood away from the fetal kidney in order to protect the fetal brain may result in a decreased number of nephrons and reduced renal reserve for postnatal challenges. ${ }^{17}$ Modification of the structure of the large conduit arteries in order to maintain fetal circulation may lead to blood vessels that are less compliant in adult life. ${ }^{18}$ In these scenarios, birth weight is an indicator of the prenatal cause, not the cause itself.

\section{BIRTH WEIGHT AS AN INDICATOR OF RISK}

Using birth weight as an indicator of risk at an individual level (for instance, to counsel the parents of a low birth weight baby) has three major problems. Firstly, risk of coronary heart disease, for example, is thought to be related to the extent of the reduction in fetal growth. However, we do not know how much a baby should have weighed, only what it actually weighs. A $3500 \mathrm{~g}$ baby who should have weighed $4000 \mathrm{~g}$ is just as growth retarded as a $2300 \mathrm{~g}$ baby who should 
have weighed 2600 g. Furthermore a $3500 \mathrm{~g}$ baby may be perfectly grown, growth retarded, or even "overgrown", depending on its genetic potential. Secondly, the differences in risk factor levels between birth weight groups are relatively small-systolic blood pressure may be 1 or $2 \mathrm{~mm} \mathrm{Hg}$ higher if birth weight is $500 \mathrm{~g}$ lower. However, whereas it may make little difference to an individual to reduce his or her blood pressure by such small amounts, if the population mean blood pressure decreased by about $6 \mathrm{~mm}$ $\mathrm{Hg}$, then approximately $30 \%$ of all strokes would be prevented. ${ }^{19}$ Thirdly, parents tend to be interested in risk in terms of longevity or quality of life, whereas the research perspective (and therefore the available evidence) has usually been focused on the prediction of specific diseases or risk factors. This points to the need for "consumers" to be involved in all parts of the research process..$^{21}$

\section{"Promotion of infant growth and avoidance of childhood obesity are both goals with immediate as well as long term benefits and may be worth emphasising to parents."}

Of particular interest to paediatricians are pathologically growth retarded babies. In theory, these infants may be at very high risk of cardiovascular disease in adult life. Currently, empirical evidence is lacking, as the subjects in most cohort studies of very low birthweight survivors have yet to reach adulthood and thus stable indicators of cardiovascular risk. In addition, some of these infants were also born prematurely. Although most studies have indicated that it is growth for gestational age rather than duration of gestation itself that is associated with adult health, few have had the statistical power to look at the separate effects. In the single study that has, raised blood pressure was associated with both reduced growth for gestational age and reduced gestation. So the highest blood pressures were found in those who grew less well in utero and were delivered early. However, the ranges of gestation studied were only from 35 to 44 weeks. ${ }^{22}$ Thus the long term health risks of babies born very early or very small remain uncertain.

If part of the risk of adult disease is set before birth, what positive messages can paediatricians give to the parents of neonates who may be at high risk? Recent research has focused on the extent to which postnatal growth can modify or add to the risks established in utero. Both poor infant growth and excessive weight gain in childhood seem to be associated with increased cardiovascular risk. ${ }^{4}$ Promotion of infant growth and avoidance of childhood obesity are both goals with immediate as well as long term benefits and may be worth emphasising to parents.

Arch Dis Child Fetal Neonatal Ed 2002;86: F7-F8

\section{Author's affiliations}

C M Law, MRC Environmental Epidemiology Unit, Southampton General Hospital,

Southampton SO16 6YD, UK

Correspondence to: Dr Law; claw@ mrc.soton.ac.uk

\section{REFERENCES}

Office for National Statistics. Mortality statistics: childhood, infant and perinatal, series $\mathrm{DH}$, no.32. London: The Stationery Office, 1999 .

2 Bernstein IM, Horbar JD, Badger GJ, et al. Morbidity and mortality among very-low-birth-weight neonates with intrauterine growth restriction. Am J Obstet Gynecol 2000; 182: 198-206.

3 Murphy D, Sellers S, MacKenzie I, et al. Case-control study of antenatal and intrapartum risk factors for cerebral palsy in very preterm singleton babies. Lancet 1995;346: 1449-54.

4 Eriksson JG, Forsen T, Tuomilehto J, et al. Early growth and coronary heart disease in later life: longitudinal study. BM 2001;322:949-53.
5 Osmond C, Barker DJP, Winter PD, et al. Early growth and death from cardiovascular disease in women. BM 1993;307:1519-24.

6 Rich-Edwards J, Stampfer M, Manson JE, et al. Birth weight and risk of cardiovascular disease in a cohort of women followed up since 1976. BM 1997:315:396-400.

7 Leon DA, Lithell HO, Vagero D, et al. Reduced fetal growth rate and increased risk of death from ischaemic heart disease: cohort study of 15,000 Swedish men and women born 1915-29. BMV 1998;317:241-5.

8 Huxley RR, Shiell AW, Law CM. The role of size at birth and postnatal catch-up growth in determining systolic blood pressure: a systematic review of the literature. $J$ Hypertens 2000;18:815-31.

9 Phillips DIW. Birth weight and the future development of diabetes. Diabetes Care 1998;21:B150-5.

10 Barker DJP, Martyn CN, Osmond C, et al. Growth in utero and serum cholesterol concentrations in adult life. BM 1993;307: 1524-8.

11 Ekbom A, Hsieh CC, Lipworth L, et al. Perinatal characteristics in relation to incidence of and mortality from prostate cancers. BM 1996;313:337-41.

12 Vatten L. Can prenatal factors influence future breast cancer risk? Lancet 1996;348: 1531.

13 Parsons TJ, Power C, Ogan S, et al. Childhood predictors of adult obesity: a systematic review. Int J Obes Relat Metab Disord 1999;23:S1-107.

14 Dabelea D, Pettitt DJ, Hanson RL, et al. Birth weight, type 2 diabetes, and insulin resistance in Pima Indian children and young adults. Diabetes Care 1999;22:944-50.

15 Rich-Edwards JW, Colditz GA, Stampfer M, et al. Birth weight and the risk for Type 2 diabetes mellitus in adult women. Ann Intern Med 1999;130:278-84.

16 Lucas A. Programming by early nutrition in man. In: Bock GR, Whelan J, eds. The childhood environment and adult disease. Chichester: Wiley, 1991;38-50.

17 Mackenzie HS, Lawler EV, Brenner BM. Congenital oligonephropathy: the fetal flaw in essential hypertension? Kidney Int 1996:49:S30-4.

18 Martyn CN, Greenwald SE. Impaired synthesis of elastin in walls of aorta and large conduit arteries during early development as an initiating event in pathogenesis of systemic hypertension. Lancet 1997;350:953-5.

19 Rose G. The strategy of preventive medicine. Oxford: Oxford University Press, 1992.

20 Consumers in NHS Research. Research: who's learning? London: Department of Health, 2000;1-41.

21 Department of Health. A research and development strategy for public health. London: The Stationery Office, 2001.

22 Leon DA, Johansson M, Rasmussen F. Gestational age and growth rate of fetal mass are inversely associated with systolic blood pressure in young adults: an epidemiologic study of 165,136 Swedish men aged 18 years. Am J Epidemiol 2000;152:597-604. 